\title{
Noradrenergic Inhibition of Synaptic Transmission between Mitral and Granule Cells in Mammalian Olfactory Bulb Cultures
}

\author{
Paul Q. Trombley and Gordon M. Shepherd \\ Section of Neurobiology, Yale University Medical School, New Haven, Connecticut 06510
}

\begin{abstract}
Noradrenergic modulation of the glutamatergic-GABAergic synapses between mitral/tufted $(M / T)$ and granule cells has been implicated in some forms of olfactory learning (Brennan et al., 1990). Norepinephrine (NE) has been shown to disinhibit mitral cells (Jahr and Nicoll, 1982), but its site of action is not well defined. The effects of NE on synaptic transmission between monosynaptically coupled pairs of mitral and granule cells have been examined using primary culture and whole-cell recording techniques. Intracellular stimulation of M/T cells evoked dual-component EPSPs in granule cells consisting of both NMDA and AMPA ( $\alpha$-amino-3-hydroxy-5methyl-4-isoxazoleproprionic acid) receptor-mediated mechanisms. The EPSPS were reversibly inhibited by approximately $50 \%$ during application of $30 \mu \mathrm{M}$ NE. NE had no effect, however, on the membrane current evoked by exogenous application of glutamate, indicating a presynaptic site of action. The effect of NE on EPSPs was mimicked by the $\alpha$-adrenergic agonist clonidine but not by the $\beta$-adrenergic agonist isoproterenol. NE had no significant effect on either accommodation or macroscopic currents in either $\mathrm{M} / \mathrm{T}$ or granule cells. NE also inhibitod spontaneous GABAergic IPSPs recorded in M/T cells, by a presynaptic $\alpha$-adrenergicmediated mechanism. These results support previous results suggesting a disinhibitory role for NE in the olfactory bulb. This action, however, is at least in part mediated by a reduction in mitral cell-mediated granule cell excitation.
\end{abstract}

In recent years the olfactory system has emerged as a model in which well-defined behavioral consequences of learning can be correlated with cellular and molecular mechanisms, including changes in physiology, anatomy, and metabolism (Coopersmith and Leon, 1984; Wilson et al., 1987; Woo et al., 1987). Much of this experience-dependent plasticity takes place in the olfactory bulb, where recent evidence suggests that modulation of the synaptic connections between mitral and granule (GR) cells mediate these changes (Brennan et al., 1990).

Olfactory learning is critically influenced by interactions between glutamate, GABA, and norepinephrine (NE) (for reviews, see Leon, 1987; Brennan et al., 1990), transmitters that have been implicated in synaptic modulation/plasticity in several regions of the mammalian brain, including the hippocampus

\footnotetext{
Received Mar. 2, 1992; revised May 11, 1992; accepted May 13, 1992.

This work was supported by NRSA Grant F32 DC 0007201 to P.Q.T. and by research grants from the NIDCD and NINDS to G.M.S. We thank Dr. Charles Greer for reading earlier versions of the manuscript.

Correspondence should be addressed to Paul Q. Trombley, Section of Neurobiology, Yale Medical School, 333 Cedar Street, New Haven, CT 06510.

Copyright (c) 1992 Society for Neuroscience $0270-6474 / 92 / 123985-07 \$ 05.00 / 0$
}

(Hopkins and Johnston, 1984; Davies et al., 1991) and the visual cortex (Bear and Singer, 1986; Kleinschmidt et al., 1987). Most excitatory synaptic pathways use glutamate as a transmitter (Mayer and Westbrook, 1987). In the olfactory bulb, the excitatory connections include the mitral/tufted $(\mathrm{M} / \mathrm{T})$ cell dendrodendritic, recurrent axon collateral synapses within the bulb, and the $\mathrm{M} / \mathrm{T}$ cell output via the lateral olfactory tract to the olfactory cortex (Mori, 1987; Trombley and Westbrook, 1990). The main inhibitory transmitter in the mammalian brain is GABA (Stepheson and Dolphin, 1989). GABAergic interneurons in the olfactory bulb include both internal GR cells in the GR cell layer and external GR cells (periglomerular cells) in the glomerular layer (Ribak et al., 1977; Jahr and Nicoll, 1980; Nowycky et al., 1981). These two populations of GABAergic neurons reflect the two levels of local circuit processing that occur in the olfactory bulb, the external plexiform layer and the glomerular layer, respectively.

The olfactory bulb also receives a dense projection of noradrenergic fibers from the locus coeruleus that terminate at all levels of the olfactory bulb (Shipley et al., 1985). Recent evidence demonstrated that some forms of olfactory learning require the activation of adrenergic receptors (Kaba and Keverne, 1988; Sullivan et al., 1989). It was further suggested that a locus for learning is the putative glutamatergic-GABAergic synaptic contacts between mitral and GR cells (Brennan et al., 1990). Although detailed studies examining the synaptic effects of NE are lacking, in the turtle olfactory bulb, NE acts to disinhibit mitral cells (Jahr and Nicoll, 1982). However, the site of NE action and the mechanism are not yet clearly defined.

In this report, we use primary olfactory bulb cultures and whole-cell recording techniques to examine the effects of NE on identified mitral/GR cell pairs. In particular, we sought to examine potential neuromodulatory mechanisms at the level of the single synapse that might be relevant to olfactory learning. We report here that NE acts to reduce excitatory synaptic transmission between monosynaptic pairs of mitral/GR cells. This effect may enhance mitral cell excitability through a reduction in reciprocal inhibition from GR cells.

\section{Materials and Methods}

Cell culture. Primary dissociated cultures of the olfactory bulb were prepared using methods similar to those described in Trombley and Westbrook (1990). The olfactory bulbs were dissected from 1-2-d-old rat pups and cut into several pieces after the meninges were removed. The tissue was incubated at $37^{\circ} \mathrm{C}$ for $45-60 \mathrm{~min}$ in a calcium-buffered solution containing $20 \mathrm{U} / \mathrm{ml}$ papain (Worthington) and $1 \mathrm{mM}$ cysteine. The tissue was gently triturated using a fire-polished Pasteur pipette, after inactivation of the enzyme with $2.5 \mathrm{mg} / \mathrm{ml}$ bovine serum albumin and $2.5 \mathrm{mg} / \mathrm{ml}$ trypsin inhibitor (Sigma, type II). The cell suspension 
was plated at low density $\left(26,000 / \mathrm{cm}^{2}\right)$ in $35 \mathrm{~mm}$ culture dishes (Corning) containing a previously prepared confluent layer of olfactory bulb astrocytes. The neuronal growth medium contained 95\% Minimal Essential Medium (MEM; GIBCO) with 5\% horse serum, $6 \mathrm{gm} / \mathrm{liter}$ glucose, and a nutrient supplement (Serum Extender, Collaborative Research, Inc.). Astrocyte feeder layers were prepared by plating a suspension of olfactory bulb cells, prepared as described above, in a $75 \mathrm{~cm}^{2}$ flask containing MEM with $10 \%$ fetal calf serum and $6 \mathrm{gm} /$ liter glucose. When the astrocytes reached confluence, they were removed with $0.125 \%$ trypsin, resuspended, and plated onto $35 \mathrm{~mm}$ dishes coated with collagen (Vitrogen, Collagen Corp.) and poly-L-lysine (30,000-70,000 MW; 10 $\mu \mathrm{g} / \mathrm{ml}$; Sigma). 5'-Fluoro-2-deoxyuridine and uridine $(15$ and $35 \mu \mathrm{g} / \mathrm{ml}$, respectively) were added $1 \mathrm{~d}$ after plating neurons to prevent overgrowth of background cells. Electrophysiological recordings were made after $7-$ $10 \mathrm{~d}$ in culture.

Presumptive M/T and GR cells were identified based on the morphological, physiological, and immunohistochemical criteria established in Trombley and Westbrook (1990). Briefly, the cultures contained two morphologically distinct populations of neurons: a small number of large-diameter pyramidal-shaped neurons $(20-40 \mu \mathrm{m}$ soma) and a much larger population of small-diameter bipolar neurons (5-10 $\mu \mathrm{m}$ soma). These correlate with $\mathrm{M} / \mathrm{T}$ and granule/periglomerular cells, respectively. Intracellular stimulation of the neurons with morphology reflecting $\mathrm{M} / \mathrm{T}$ cells in vivo invariably evoked EPSPs in adjacent neurons. Intracellular stimulation of the small bipolar neurons, however, evoked picrotoxin-sensitive IPSPs. These morphologically distinct populations could also be identified by immunohistochemical markers. The large pyramidal neurons, the presumptive $\mathrm{M} / \mathrm{T}$ cells, were $N$-acetylaspartylglutamate immunoreactive; in contrast, the small bipolar neurons, presumptive granule/periglomerular neurons, were glutamic acid decarboxylase immunoreactive.

Electrophysiology. Voltage- and current-clamp recordings were performed at room temperature on the stage of an inverted phase-contrast microscope. The recording chamber was perfused at $0.5-2.0 \mathrm{ml} / \mathrm{min}$ with a solution containing (in $\mathrm{mM}$ ) $\mathrm{NaCl}, 162.5 ; \mathrm{KCl}, 2.5 ; \mathrm{CaCl}_{2}, 2$; HEPES, $10 ;$ glucose, $10 ; \mathrm{MgCl}_{2}, 0$ or 1 ; and glycine, 0 or $1 \mu \mathrm{M}$. The $\mathrm{pH}$ was adjusted to 7.3 with $\mathrm{NaOH}$ and the final osmolarity was $325 \mathrm{mOsm}$. Picrotoxin $(20 \mu \mathrm{M})$ was used in some experiments to block inhibitory synaptic activity. Patch electrodes were pulled from borosilicate glass, fire polished, and filled with solution containing (in $\mathrm{mM}$ ) $\mathrm{KMeSO}_{4}$ or CsCl, 145; $\mathrm{MgCl}_{2}, 1$; HEPES, 10; $\mathrm{Mg}$-ATP, 4; Mg-GTP, 0.5; and EGTA, 1.1 or $11 ; \mathrm{pH} \mathrm{7.2,} \mathrm{osmolarity} 310$. Electrode resistances were 4-6 M 2 . Drugs were diluted in the recording solution and applied using a gravityfed flow pipe perfusion system, consisting of an array of $400-\mu \mathrm{m}-\mathrm{i} . \mathrm{d}$. glass barrels. The flow pipes were aligned with the neuron using a hydraulic manipulator, and flow was controlled with pinch clamps. Although no attempt was made in these experiments to optimize the speed of solution changes, peak drug responses occurred within 200-500 msec. Neurons were always bathed with fast flow from one barrel containing control solution except during application of drugs. Drugs applied were 6-cyano-2,3-dihydroxy-7-nitroquinoxaline (CNQX; Cambridge $\mathrm{Re}$ search Biochemicals); DL-2-amino-5-phosphonovalerate (AP5), norepinephrine (NE), clonidine, isoproterenol, glutamate, picrotoxin, and GABA (Sigma).

Experimental procedures. To examine excitatory postsynaptic potentials (EPSPs), simultaneous whole-cell recordings were made from monosynaptically coupled $M / T-G R$ cell pairs in current-clamp mode with an Axoclamp 2A amplifier (Axon Instruments). Both patch electrodes contained $\mathrm{KMeSO}_{4}$-based solutions; membrane potentials were maintained near $-60 \mathrm{mV}$ using small holding currents $( \pm 20 \mathrm{pA})$. Action potentials were evoked in the $M / T$ neuron by injection of a brief ( 2 msec) depolarizing current pulse at $0.25-0.5 \mathrm{~Hz}$. EPSPs were considered monosynaptic if there was no intertrial variation in latency and the latency was $<5 \mathrm{msec}$. The evoked EPSPs were filtered at $1-3 \mathrm{kHz}$ with an eight-pole Bessel filter, digitized at $5-10 \mathrm{kHz}$, and analyzed using pCLAMP software (Axon Instruments) on an IBM-386 computer.

Whole-cell recordings were made from $\mathrm{M} / \mathrm{T}$ cells in primary cultures of olfactory bulb neurons plated at $50,000-75,000 / \mathrm{cm}^{2}$ to examine the effects of NE, clonidine, and isoproterenol on spontaneous IPSPs. Experiments examining the direct effects of $N E$ on $M / T$ and $G R$ cells used palch electrodes containing a $\mathrm{KMeSO}_{4}$-based solution.

To examine responses evoked by glutamate and GABA, whole-cell voltage-clamp recordings were made using the discontinuous singleelectrode voltage-clamp mode at a switch frequency of $10-15 \mathrm{kHz}$. The patch electrodes contained a CsCl-based solution, and tetrodotoxin $(300$
nM) was added to the extracellular solution. Agonist-evoked currents were filtered at $1-3 \mathrm{kHz}$ and digitized at $5-10 \mathrm{kHz}$.

All data are expressed as mean $\pm \mathrm{SD}$.

\section{Results}

Effects of glutamate receptor antagonists on EPSPs evoked in $G R$ cells

Using simultaneous whole-cell recording from monosynaptically coupled pairs of M/T-GR cells, EPSPs were readily evoked by depolarizing current injection in the presynaptic $\mathrm{M} / \mathrm{T}$ neuron. Polysynaptic contamination of evoked EPSPs was minimized by plating neurons at low density and blocking IPSPs with picrotoxin. In external solutions containing $1 \mu \mathrm{M}$ glycine and no added $\mathrm{Mg}$, the evoked EPSPs had a rapid rise rate and slow decay, sometimes lasting more than $500 \mathrm{msec}$ (Fig. $1 \mathrm{~B}$ ). In the presence of the selective NMDA receptor antagonist AP5, the duration of the EPSPs was markedly reduced, demonstrating that the control EPSPs contained a substantial NMDA receptormediated component. The fast AP5-resistant component was characterized by a rapid rise and a decay phase that approximated the membrane time constant of the postsynaptic cell. CNQX $(2.5 \mu \mathrm{M})$ blocked the fast component of the EPSP indicative of an AMPA receptor-mediated potential. The EPSPS were completely blocked in the presence of both AP5 and CNQX. All of the pairs examined with AP5 or CNQX produced dualcomponent EPSPs $(n=9)$, although the ratio of the peak amplitudes of the fast and slow components varied. These results suggest that both NMDA and AMPA receptors participate in $\mathrm{M} / \mathrm{T}$ cell-mediated excitation of GR cells.

\section{Effects of NE on EPSPS}

The actions of NE on evoked EPSPs in GR cells were also studied using simultaneous whole-cell recordings from monosynaptically coupled pairs of $\mathrm{M} / \mathrm{T}$ and GR cells. Flow pipe application of $30 \mu \mathrm{M} N E$ rcduced the amplitude of M/T cellevoked EPSPs recorded in GR cells by $53 \pm 14 \%$ in 11 out of 11 pairs (Fig. $2 A$ ). To determine the locus of NE's action, we examined the possible postsynaptic action of NE on GR cells using whole-cell voltage-clamp recordings. At a holding potential of $-60 \mathrm{mV}$, flow pipe application of $10 \mu \mathrm{M}$ glutamate, in $2.5 \mu \mathrm{M}$ CNQX, no added $\mathrm{Mg}$, and $1 \mu \mathrm{M}$ glycine, evoked a desensitizing inward current with an increase in current noise in GR cells consistent with the selective activation of NMDA receptors. Application of $500 \mu \mathrm{M}$ glutamate in $100 \mu \mathrm{M}$ AP5, 1 $\mathrm{mM} \mathrm{Mg}$, and no added glycine evoked a sustained inward current consistent with the selective application of AMPA receptors (Patneau and Mayer, 1990). Coapplication of $30 \mu \mathrm{M}$ NE did not affect the glutamate-mediated current in any of the cells examined $(n=6)$, suggesting that the site of NE's action was presynaptic (Fig. $2 B, C$ ).

\section{Pharmacology}

To determine the identity of the adrenergic receptors mediating NE's action on EPSPs, we examined the effects of the $\alpha_{2}$-selective agonist clonidine and the $\beta$-adrenergic receptor agonist isoproterenol. Monosynaptic EPSPs evoked by stimulation of $\mathrm{M} / \mathrm{T}$ and recorded in GR cells were inhibited by clonidine $(40 \pm$ $13 \%$ reduction; $n=5$ ) but not by isoproterenol ( $n=7$; Fig. 3 ). These results and the lack of a noradrenergic effect on glutamatemediated currents suggest that the effects of NE were mediated by presynaptic $\alpha_{2}$-adrenergic receptors. 


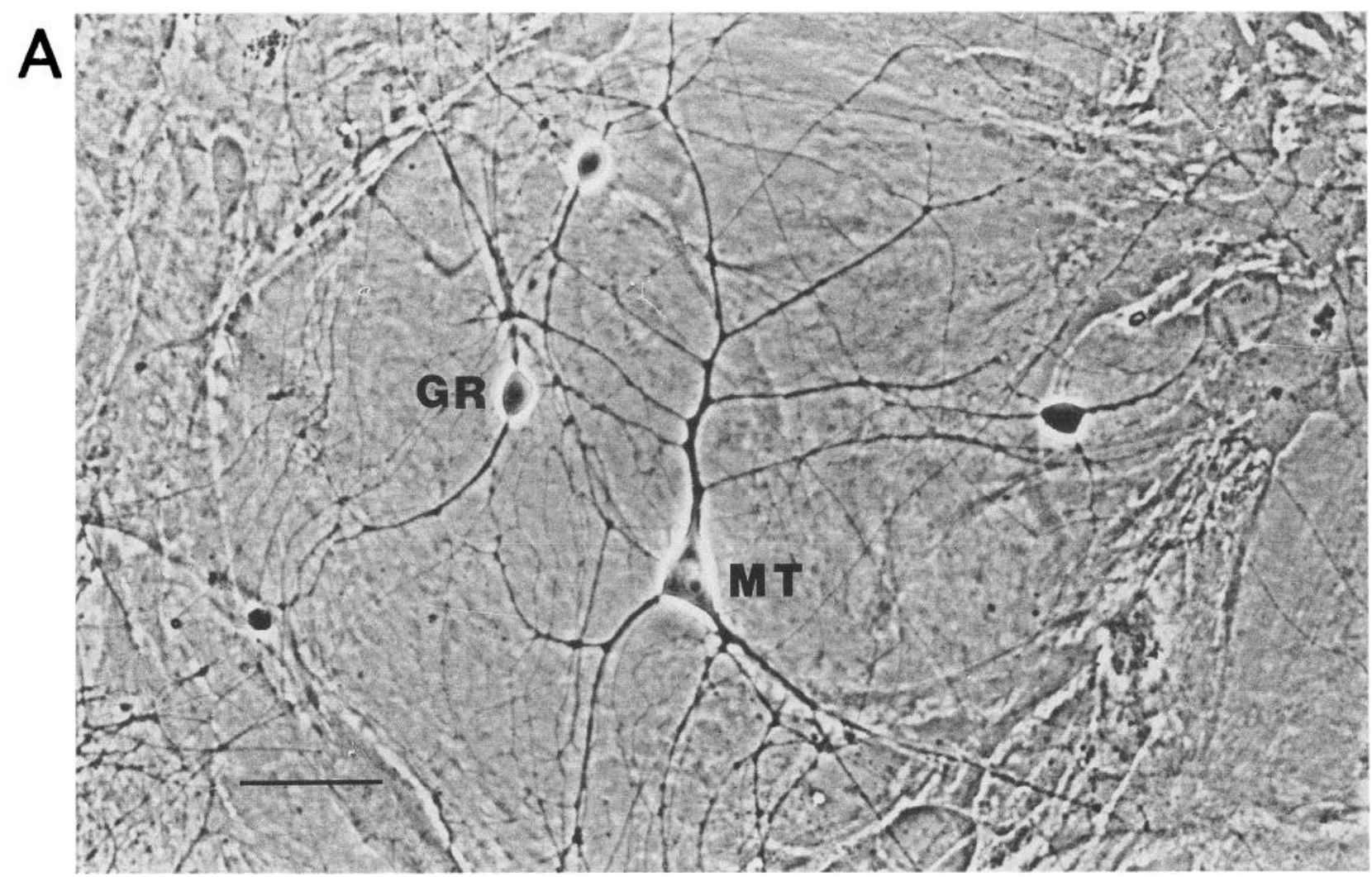

B
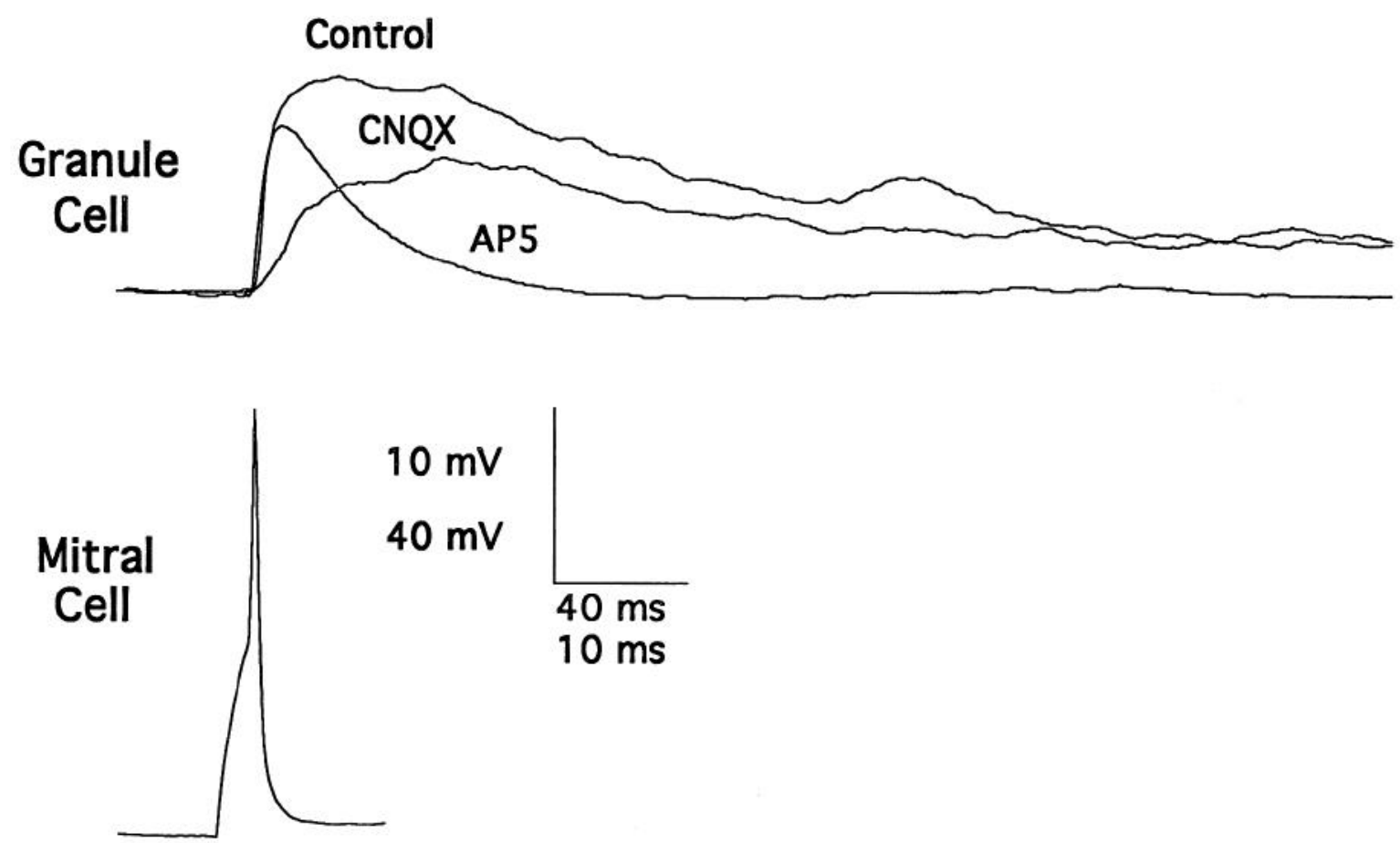

Figure 1. Mitral cell-evoked EPSPs in GR cells are mediated by both NMDA and AMPA receptors. $A$, Phase-contrast photograph of a putative $\mathrm{M} / \mathrm{T}(M T)$ cell and three putative GR cells from the olfactory bulb of a neonatal rat pup after $7 \mathrm{~d}$ in primary culture. Scale bar, $40 \mu \mathrm{m}$. $B$, Simultaneous whole-cell recordings were made from a monosynaptically coupled M/T-GR cell pair. In whole-cell current-clamp mode, a 2 msec depolarizing current pulse generated an action potential in the M/T cell (lower trace). The M/T cell action potential evoked an EPSP in the GR cell (upper traces). Flow pipe application of $100 \mu \mathrm{M}$ AP5 blocked a slow component of the response that was resistant to $2.5 \mu \mathrm{M}$ CNQX. The results were indicative of a dual postsynaptic receptor mechanism as coapplication of AP5 and CNQX completely blocked the response. Extracellular solution contained $1 \mu \mathrm{M}$ glycine and no added $\mathrm{Mg}$. $\mathrm{KMeSO}_{4}$ patch solution. Membrane potential, $-60 \mathrm{mV}$. 
Figure 2. NE reversibly inhibited F.PSPs. $A$, An EPSP in a GR cell was evoked by intracellular stimulation of a monosynaptically coupled $\mathrm{M} / \mathrm{T}$ cell. Flow pipe application of $30 \mu \mathrm{M} \mathrm{NE}$ reversibly reduced the EPSPs by approximately $50 \%$. $\mathrm{KMeSO}_{4}$ patch solution. $B$, Under voltage clamp, flow pipe application of $10 \mu \mathrm{M}$ glutamate results in an inward current through NMDA receptors in a GR cell that was not antagonized by coapplication of $30 \mu \mathrm{M}$ NE. External solution: $2.5 \mu \mathrm{M}$ CNQX, $0 \mathrm{Mg}, 1 \mu \mathrm{M}$ glycine. $C$, Flow pipe application of $500 \mu \mathrm{M}$ glutamate in the presence of $1 \mathrm{mM} \mathrm{Mg}$, no added glycine, and $100 \mu \mathrm{M}$ AP5 evoked an inward current through AMPA receptors that also was not antagonized by coapplication of $30 \mu \mathrm{M}$ NE. $A-C$, Holding potential, $-60 \mathrm{mV} . B$ and $C, \mathrm{CsCl}$ patch solution.
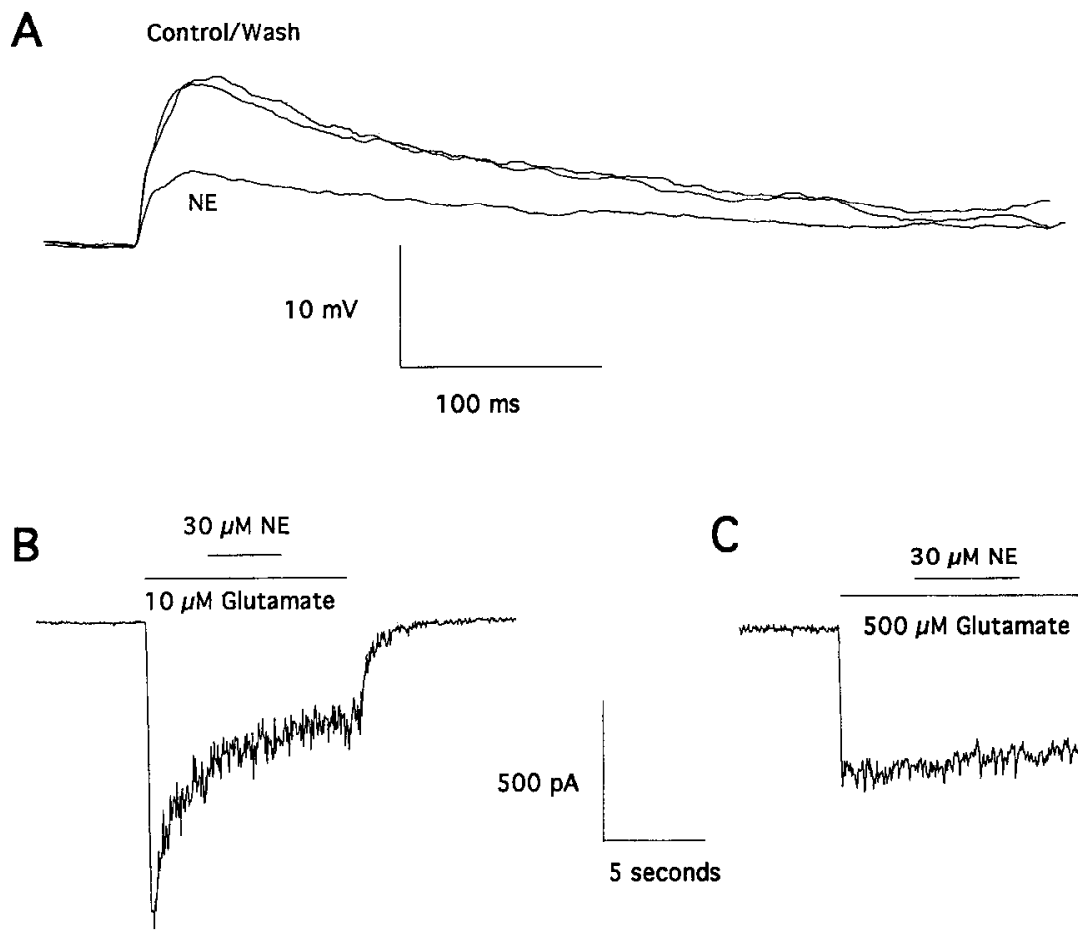

\section{Direct effects of $N E$}

We used both whole-cell current- and voltage-clamp recordings to reveal any direct effects NE might have on either $M / T$ or GR cells. Under voltage clamp, flow pipe application of $30 \mu \mathrm{M} \mathrm{NE}$

Control
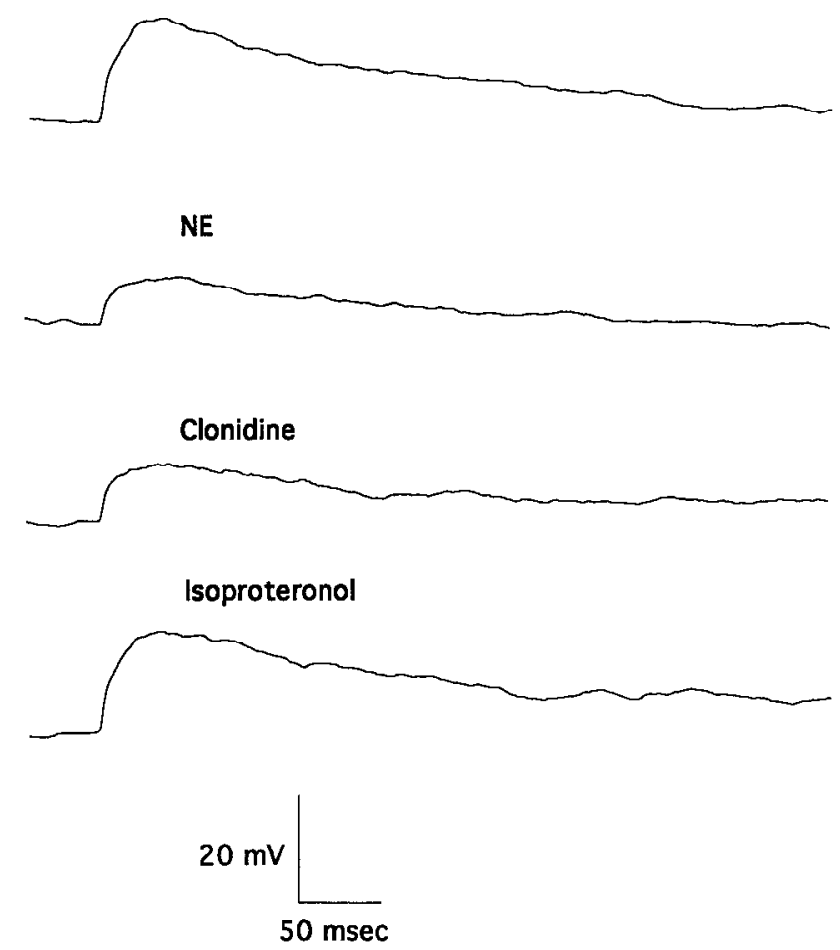

Figure 3. The effects of NE on EPSPs are mimicked by $\alpha_{2}$-adrenergic receptor agonists. NE $(30 \mu \mathrm{M})$ reduced mitral to granule EPSPs by $52 \%$. This effect is similar to the effects of $1 \mu \mathrm{M}$ clonidine, which inhibited the EPSPs by $47 \%$. The amplitude of the EPSPs during application of $1 \mu \mathrm{M}$ isoproterenol, however, was similar to control. Solutions were the same as for Figure 1. did not evoke any detectable current in either M/T or GR cells ( $n=12$; data not shown). NE also had no marked effect on membrane currents evoked by $10 \mathrm{mV}, 50 \mathrm{msec}$ steps from -60 $\mathrm{mV}$ to $+10 \mathrm{mV}$ in either M/T or GR cells $(n=9$; Fig. $4 B)$. Similar results were seen using voltage ramps (data not shown). In hippocampal pyramidal neurons, $\mathrm{NE}$ acts to reduce accommodation that results in a higher frequency of firing in response to depolarizing current injection (Madison and Nicoll, 1982). To examine the effects of NE on accommodation in both $\mathrm{M} / \mathrm{T}$ and GR cells, we made whole-cell recordings in current-clamp mode and induced repetitive firing using low-amplitude 500 msec depolarizing current pulses. Neither M/T (Fig. 4A) nor GR cells (not shown) showed any change in firing frequency in response to $30 \mu \mathrm{M}$ NE. These results suggest that NE does not have any marked effects on accommodation or membrane currents recorded under our experimental conditions.

\section{Noradrenergic disinhibition}

NE dramatically reduced spontaneous GABAergic IPSPs recorded in $\mathrm{M} / \mathrm{T}$ cells (76 $\pm 17 \%$ reduction; $n=4)$. This effect was mimicked by the $\alpha_{2}$-adrenergic receptor agonist clonidine (Fig. $5 A$ ) but not by the $\beta$-adrenergic agonist isoproterenol (not shown). To determine if the effect of NE was via inhibition of postsynaptic GABA receptors, we examined the effects of NE on GABA-mediated currents. Under voltage clamp at a holding potential of $-60 \mathrm{mV}$, rapid perfusion with $100 \mu \mathrm{M}$ GABA evoked a desensitizing inward current. Coapplication of NE during the current was without detectable effect (Fig. 5B). These results suggest that the decrease in IPSPs was not due to noradrenergic antagonism of postsynaptic GABA receptors on $M / T$ cells.

\section{Discussion}

The results of these experiments demonstrate that mitral cell excitation of GR cells is mediated by a dual postsynaptic receptor mechanism involving the activation of both the NMDA 
A

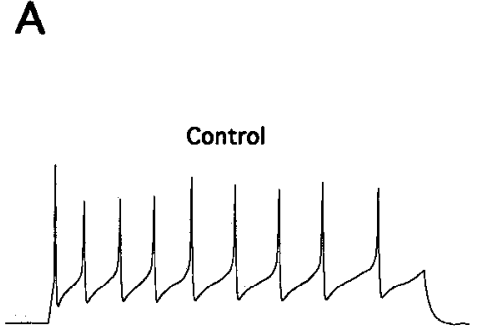

B

Mitral

Granule

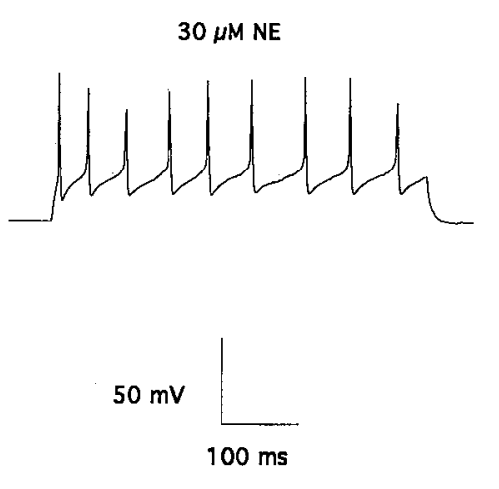

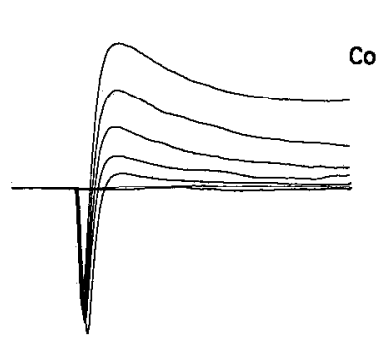

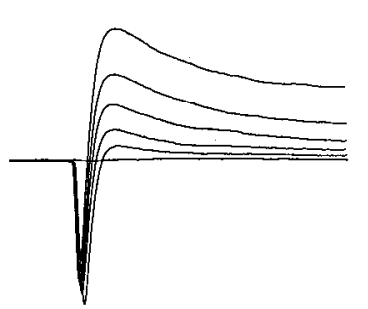

1 nA:500 pA
Control

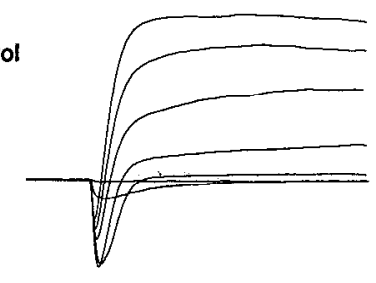

$\mathrm{NE}$

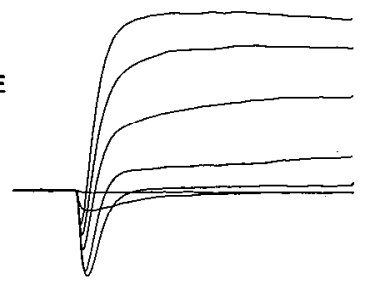

Figure 4. NE had no direct action on either M/T or GR cells. $A$, Under current clamp, a $500 \mathrm{msec}$ depolarizing current pulse results in repetitive firing in an $\mathrm{M} / \mathrm{T}$ cell. Application of $30 \mu \mathrm{M}$ NE did not change firing frequency. Similar results were seen for GR cells (not shown). $B$, Under voltage clamp, $10 \mathrm{mV}$ step depolarizations from -60 $\mathrm{mV}$ to $+10 \mathrm{mV}$ evoked a family of inward and outward currents. Rapid perfusion with $30 \mu \mathrm{M}$ NE did not effect the evoked currents. $\mathrm{KMeSO}_{4}$ patch solution.

and AMPA subtypes of excitatory amino acid receptors. NE inhibited monosynaptic EPSPs recorded in GR cells but did not block currents evoked by flow pipe application of glutamate. The effect of NE on EPSPs was mimicked by the $\alpha$-adrenergic receptor agonist clonidine but not by the $\beta$-adrenergic receptor agonist isoproterenol. NE and clonidine, but not isoproterenol, also reduced spontaneous GABAergic IPSPs in mitral cells. NE, however, had no effect on currents mediated by exogenous application of GABA. We conclude that NE disinhibits mitral cells by reducing mitral cell excitation of GR cells via a presynaptic $\alpha_{2}$-adrenergic receptor mechanism.

\section{$N M D A$ receptors participate in excitation of $G R$ cells}

Trombley and Westbrook (1990) recently provided evidence that $\mathrm{M} / \mathrm{T}$ cells likely use glutamate as a transmitter. The results presented here demonstrate further that both the NMDA and the AMPA subtypes of the excitatory amino acid receptor family are activated during mitral cell-mediated excitation of GR cells. These results are consistent with several earlier reports using extracellular field potential recording techniques. Jacobson and Hamberger (1986) reported that the nonselective excitatory amino acid receptor antagonist kynurenic acid blocked the ex-
A
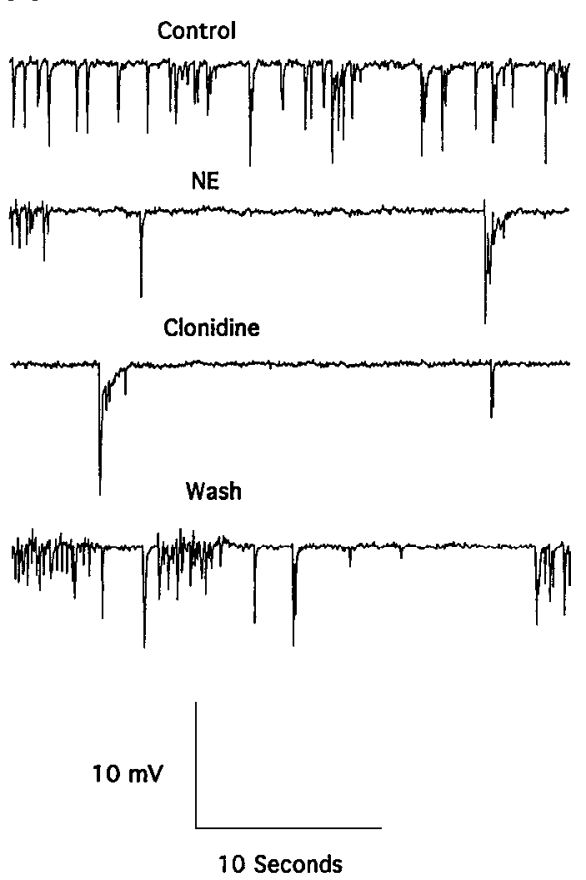

B

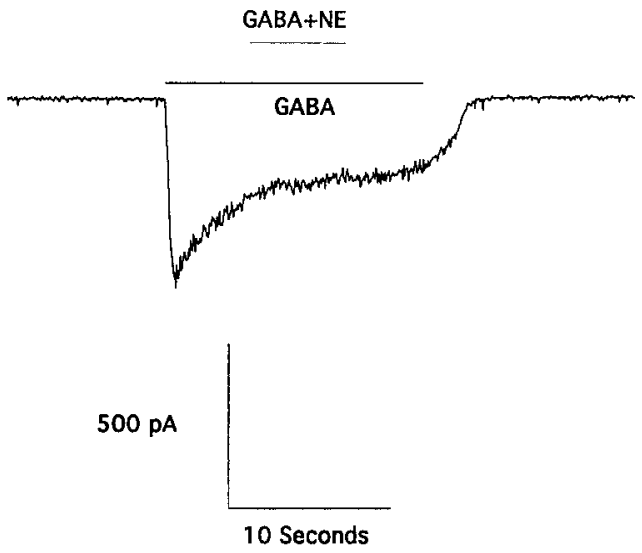

Figure 5. NE also reduced IPSPs by a presynaptic mechanism. $A$, Spontaneous GABAergic IPSPs recorded in an $\mathrm{M} / \mathrm{T}$ cell are reduced by $30 \mu \mathrm{M} \mathrm{NE}$. The cffects of NE are mimicked by the $\alpha-2$ adrenergic receptor agonist clonidine (1 $\mu \mathrm{M})$ but not by the $\beta$-adrenergic receptor agonist isoproterenol $(1 \mu \mathrm{M})$. $\mathrm{KMeSO}_{4}$ electrode. $B$, Under voltage clamp, $100 \mu \mathrm{M} \mathrm{GABA}$ evokes a desensitizing inward current that is not antagonized by coapplication of $30 \mu \mathrm{M}$ $\mathrm{NE}$, suggesting a presynaptic site for the action of NE on IPSPs. $\mathrm{CsCl}$ patch solution. Holding potential, $-60 \mathrm{mV}$. 
citation of GR cells from retrograde stimulation of $\mathrm{M} / \mathrm{T}$ cells. Additional studies demonstrated that field responses in the olfactory bulb, consistent with the time course of monosynaptically activated NMDA receptors, were sensitive to the NMDA receptor antagonist AP5 (Collins, 1982; Jacobson et al., 1986). In our experiments, synaptic activation of NMDA receptors resulted in long-lasting depolarization of the GR cell, an effect that may prolong inhibition of mitral cells from the sustained release of GABA at GR-M/T dendrodendritic synapses.

\section{$N E$ reduces $G R$ cell excitability via presynaptic $\alpha$-receptors}

NE can exert several different actions on neurons via either $\beta$ or $\alpha$-adrenergic receptors depending on the brain region examined (see Surprenant, 1989, for review). However, under the conditions of our experiments, NE did not have any direct effects on either mitral or GR cells or affect membrane currents evoked by either voltage ramps or discrete voltage steps. A similar lack of obvious effect of NE on mitral cells was observed by Jahr and Nicoll (1982). In the hippocampus, NE acts on $\beta$-receptors to inhibit the calcium-activated potassium conductance, $I_{\mathrm{AHP}}$. As a consequence, NE reduces accommodation in pyramidal neurons by increasing action potential firing (Madison and Nicoll, 1982), an effect we did not observe in olfactory bulb neurons. NE did, however, produce profound inhibition of mitral cell-mediated excitation of GR cells. Moreover, the lack of a direct effect of NE on glutamate-mediated currents in GR cells is consistent with a presynaptic site of action.

The effects of NE on monosynaptic EPSPs were mimicked by the $\alpha$-adrenergic receptor agonist clonidine but not by the $\beta$-adrenergic receptor agonist isoproterenol, suggesting an $\alpha_{2}$ adrenergic receptor-mediated mechanism. These results are supported by the recent report by Dodt et al. (1991), in which a similar decrease in glutamatergic EPSPs occurs in lamina II/ III neurons of rat frontal cortex when NE or $\alpha$-adrenergic agonists, but not $\beta$-receptor agonists, were applied. Collectively, these results suggest that noradrenergic inhibition of excitatory synaptic pathways may exist in several brain regions.

\section{$N E$ acts to disinhibit mitral cells}

It has previously been reported that NE reduced GR cell inhibition of mitral cells in slices of turtle olfactory bulb (Jahr and Nicoll, 1982). Because NE did not have any detectable direct action on mitral cells, they concluded the action was likely on the GR cells. In our experiments, spontaneous IPSPs in M/T cells were dramatically reduced in the presence of NE. However, NE did not affect membrane currents in M/T cells that were evoked by rapid perfusion with GABA. Noradrenergic depression of spontaneous IPSPs is perhaps due to decreased excitation of GR cells, both because IPSP frequency was more affected than amplitude and because spontaneous IPSPs are reduced in the presence of glutamate receptor antagonists. This conclusion is further supported by the recent results of Doze et al. (1991) that demonstrated that the disinhibitory action of NE in the rat hippocampus is due to reduced excitation of inhibitory interneurons via an $\alpha$-adrenergic receptor-mediated mechanism. Our results, however, do not exclude a presynaptic action on GR cells.

\section{Olfactory plasticity}

NMDA receptors have been shown to play a role in many forms of neuronal plasticity (see Collingridge and Singer, 1990, for review). Recently, it has been shown that NMDA receptor ac- tivation is required in some forms of olfactory learning (Lincoln et al., 1988). Rat pups, for example, can learn to prefer a novel odor when trained under specific conditions. This type of olfactory learning results not only in a behavior preference for the odor but also an enhanced uptake of $2-{ }^{14} \mathrm{C}$-deoxyglucose in the area of the glomerular layer responsive to the odor. Both effects of olfactory learning are suppressed by NMDA receptor blockade (Lincoln et al., 1988). It has also been shown that the NMDA receptor antagonist AP5 impairs memory acquisition in rats learning odor discrimination while not affecting performance of tasks dependent on recall of previously learned odors (Staubli et al., 1989). The potential for plasticity afforded by the presence of NMDA receptors on GR cells may be significant in light of recent evidence implicating synaptic connections between mitral and GR cells as loci for olfactory learning (Brennan et al., 1990).

Noradrenergic modulation of M/T-GR cell synapses via $\alpha$-adrenergic receptors also appears to be critical for some forms of olfactory learning. Adrenergic antagonists can prevent a robust example of olfactory learning referred to as pregnancy block. Pregnancy block (failure of a fertilized egg to implant in the uterus) occurs when a recently mated female mouse detects the odor of a strange male (Keverne, 1983). As a consequence of olfactory learning, the odor of her mate does not evoke this response. An $\alpha$-adrenergic receptor-mediated modulation of $\mathrm{M} / \mathrm{T}-\mathrm{GR}$ synapses, as demonstrated in our experiments, may be important in the female's learned acquisition of her mate's odor because $\alpha$-adrenergic receptor antagonists, but not $\beta$-receptor antagonists, prevent the formation of the olfactory memory revealed by pregnancy block (Kaba and Keverne, 1988)

\section{Summary}

NE, GABA, and glutamate appear necessary not only for the behavioral expression but also the anatomical, physiological, and metabolic consequences of olfactory learning. M/T-GR cell synapses may be important in mediating these processes, and the presence of NMDA receptors suggests a potential for longlasting plasticity as seen in other brain regions. Our results indicate that NE acts through activation of $\alpha$-adrenergic receptors to modulatc the efficacy of M/T-GR synapses by reducing GR cell excitation and disinhibiting mitral cells. This suggests a mechanism in which arousal, mediated through NE (AstonJones and Bloom, 1981), could influence synaptic plasticity associated with learning.

\section{References}

Aston-Jones G, Bloom FE (1981) Norepinephrine-containing locus coeruleus neurons in behaving rats exhibit pronounced responses to non-noxious environmental stimuli. J Neurosci 1:887-900.

Bear MF, Singer W (1986) Modulation of visual cortical plasticity by acctylcholine and noradrenalinc. Science 320:172-176.

Brennan P, Hideto K, Keverne EB (1990) Olfactory recognition: a simple memory system. Science 250:1223-1226.

Collingridge GL, Singer W (1990) Excitatory amino acid receptors and synaptic plasticity. Trends Pharmacol Sci 11: 290-296.

Collins GGS (1982) Some effects of excitatory amino acid receptor antagonists on synaptic transmission in the rat olfactory cortex slice. Brain Res 224:311-318.

Coopersmith R, Leon M (1984) Enhanced neural response to familiar olfactory cues. Science 225:849-851.

Davies CH, Starkey SJ, Pozza MF, Collingridge GL (1991) GABAb autoreceptors regulate the induction of LTP. Nature 349:609-611.

Dodt H-U, Pawelzik H, Zieglgansberger W (1991) Actions of noradrenaline on neocortical neurons in vitro. Brain Res 545:307-311. 
Doze VA, Cohen GA, Madison DV (1991) Synaptic localization of adrenergic disinhibition in the rat hippocampus. Neuron 6:889-900.

Hopkins WF, Johnston D (1984) Frequency-dependent noradrenergic modulation of long-term potentiation in the hippocampus. Science 226:350-351.

Jacobson I, Hamberger A (1986) Effects of kynurenic acid on evoked extracellular field potentials in the rat olfactory bulb in vivo. Brain Res 386:389-392.

Jacobson I, Butcher S, Hamberger A (1986) An analysis of the effects of excitatory amino acid receptor antagonists on evoked field potentials in the olfactory bulb. Neuroscience 19:267-273.

Jahr C.F, Nicoll RA (1980) Dendrodendritic inhibition: demonstration with intracellular recording. Science 207:1473-1475.

Jahr CE, Nicoll RA (1982) Noradrenergic modulation of dendrodendritic inhibition in the olfactory bulb. Nature 297:227-229.

Kaba H, Keverne EB (1988) The effects of microinfusions of drugs into the accessory olfactory bulb on the olfactory block to pregnancy. Neuroscience 25:1007-1011.

Keverne EB (1983) Pheromonal influences on the endocrine regulation of reproduction. Trends Neurosci 6:381-384.

Kleinschmidt A, Bear MF, Singer W (1987) Blockade of NMDA receptors disrupts experience-dependent plasticity of kitten striate cortex. Science 238:355-358.

Leon M (1987) Plasticity of olfactory output circuits related to early olfactory learning. Trends Neurosci 10:434-438.

Lincoln J, Coopersmith R, Harris EW, Cotman CW, Leon M (1988) NMDA receptor activation and early olfactory learning. Dev Brain Res 39:309-312.

Madison DV, Nicoll RA (1982) Noradrenalinc blocks accommodation of pyramidal cell discharge in the hippocampus. Nature 299:636-638.

Mayer ML, Westbrook GL (1987) The physiology of excitatory amino acids in the vertebrate central nervous system. Prog Neurobiol 28: 197-276.
Mori K (1987) Membrane and synaptic properties of identified neurons in the olfactory bulb. Prog Neurobiol 29:275-320.

Nowycky MC, Mori K, Shepherd GM (1981) GABAergic mechanisms of dendrodendritic synapses in isolated turtle olfactory bulb. J Neurophysiol 46:639-648.

Patneau DK, Mayer ML (1990) Structure-activity relationships for amino acid transmitter candidates acting at $N$-methyl-D-aspartate and quisqualate receptors. J Neurosci 10:2385-2399.

Ribak CE, Vaughn JE, Saito K, Barber R, Roberts E (1977) Glutamate decarboxylase localization in neurons of the olfactory bulb. Brain Res 126:1-18

Shipley MT, Halloran FJ, De I a Torre J (1985) Surprisingly rich projection from the locus coeruleus to the olfactory bulb in the rat. Brain Res 329:294-299.

Staubli U, Thibault O, DiLorenzo M, Lynch G (1989) Antagonism of NMDA receptors impairs acquisition but not retention of olfactory memory. Behav Neurosci 103:54-60.

Stepheson FA, Dolphin AC (1989) GABA and glycine neurotransmission. Semin Neurosci 1:115-123.

Sullivan RM, Wilson DA, Leon M (1989) Norepinephrine and learning-induced plasticity in infant rat olfactory system. J Neurosci 9: $3998-4006$.

Surprenant A (1989) The neurotransmitter noradrenaline and its receptors. Semin Neurosci 1:125-136.

Trombley PQ, Westbrook GL (1990) Excitatory synaptic transmission in primary cultures of rat olfactory bulb. J Neurophysiol 64:598-606

Wilson DA, Sullivan RM, Leon M (1987) Single-unit analysis of postnatal olfactory learning: modified olfactory bulb output response patterns to learned attractive odors. J Neurosci 7:3154-3162.

Woo CC, Coopersmith R, Leon M (1987) Localized changes in olfactory bulb morphology associated with early olfactory learning. J Comp Neurol 263:113-125. 